\title{
THE PATTERN OF BACTERIA AND ITS RESISTANCE ON ADULT SEPSIS PATIENT AT Dr. MOEWARDI GENERAL HOSPITAL, INDONESIA
}

\author{
Andika Dwi Mahendra ${ }^{1 *}$, M. Kuswandi ${ }^{2}$, and Ika Trisharyanti D. Kusuma ${ }^{1}$
}

\begin{abstract}
Background: Sepsis incidence which related with morbidity and mortality, is globally increasing. Sepsis occurs because of severe infections. Sepsis has life-threatening potential with organ disfungction complication, septic shock, and death. Alteration of resistance pattern always change at certain period. The aim of the study is to investigate the bacteria pattern and its resistance from adult sepsis patient at Dr. Moewardi Regional General Hospital.

Methods: Isolated bacteria from adult sepsis patient's blood at Dr. Moewardi Regional General Hospital. 7 bacteria isolates were taken from blood of adult sepsis patient (September - October 2014) and 46 bacteria isolates of secondary data (January - March 2014) at Dr. Moewardi Regional General Hospital. Bacteria isolation was performed based on standard Laboratory of Microbiology of Dr. Moewardi Regional General Hospital. 7 bacteria isolates were tested by using disc diffusion antibiotic on Mueller Hinton and coupled by 46 secondary data.

Results: The bacteria pattern from adult sepsis patients were Staphylococcus haemolyticus (15,09\%), Staphylococcus hominis (15,09\%), Escherichia coli (13,21\%), and Acinetobacter baumannii $(11,32 \%)$. Resistance pattern of bacteria on adult sepsis with level of resistant more than $50 \%$ as Staphylococcus haemolyticus (ciprofloxacin, erythromycin, levofloxacin, moxifloxacin, and gentamicin), Escherichia coli (gentamicin, ciprofloxacin, and levofloxacin), and Acinetobacter baumannii (gentamicin, ciprofloxacin, levofloxacin, and ceftazidime)

Conclutions: Based on this research, revealed that the most common bacteria caused sepsis was Gram negative about $64,64 \%$ of all bacteria on sepsis patient. The most frequent cause of sepsis was Staphylococcus hominis, Staphylococcus haemolyticus, and Escherichia coli.
\end{abstract}

Keywords: Sepsis, resistance, antibiotics, bacteria pattern

\section{Background}

Infection can occur because of infection agents such as bacteria, fungus, virus, and protozoa [1]. Bacteremia is state which presence of living bacteria on blood stream [2]. Bacteremia is state that determine to occur sepsis. Further, sepsis can develop to be sepsis shock and also renal and hepar disfunction with hypotension [3].

Bacteria is one of sepsis's cause. It comes from previous infections such as pulmonary infection, urinary tract infection, central nerve system infection, or Community acquired methicillin-resistant Staphylococcus aureus [3, 4]. Sepsis patients will have possibility for developing complications such as organ complications. One of factor increasing mortality on sepsis patient was organ disfunction. Mortality of sepsis patiens were estimated about $15 \%$ and increased to be $70 \%$ if patiens suffer three or more organ disfunction including pulmonary, renal, or heart [5].

Development of bacteria resistance was increasing quickly by discovering resistant bacteria against antibiotics in $1979-2011$. Some bacteria had been being resistant against antibiotics, for instance gentamicin- $R$ Enterococcus, vancomycin-R Enterococcus, levofloxacin-R Pneumococcus, imipenem-R Enterobacteriaceae, vancomicin-R Staphylococcus, ceftriaxone-R Nesseria gonorrhoeae, dan ceftaroline-R Staphylococcus [6]. Research about Escherichia coli resistance showed that 21 bacteria isolates $(0,6 \%)$ were resistant against ampicillin, chloramphenicol, gentamicin, ciprofloxacine, cefotaxime, and trimethoprim /sulfamethoxazole [7]. Lewis et al. reported that resistance also occured against ceftriaxone and imipenem on Acine-

*Correspondence: andikadwimahendra@gmail.com

${ }^{1}$ Faculty of Pharmacy, Muhammadiyah University of Surakarta, Surakarta

${ }^{2}$ Faculty of Pharmacy, University of Gadjah Mada, Sekip Utara, Yogyakarta 
tobacter spp. (28,6\% dan 10\%), Pseudomonas aeruginosa (46,7\% and 3,8\%), and Enterobacter spp. (16\% and 0\%) [8]. Research was performed at ICU room, Fatmawati hospital, Indonesia, revealed that Pseudomonas aeruginosa, Staphylococcus epidermidis, and Escherichia coli were resistant against meropenem, gentamicin, and levofloxacine [9].

\section{Method}

Bacteria was isolated by standart of microbiology laboratory in Dr. Moewardi regional general hospital and then earned pure bacteria isolate. The bacteria isolates were grown on NA (Nutrient Agar) and brought to microbiology laboratory of Faculty of Pharmacy, MUS, for being performed sensitivity test against antibiotics. Sensitivity test was carried out using disc diffusion and the results were interpreted based on CLSI (Clinical and Laboratory Standards Institute).

The bacteria isolates, from NA, were taken by using sterile inoculation loop and put into BHI medium then shaked by shaker for 2 hours. After that, took $200 \mu \mathrm{L}$ of $\mathrm{BHI}$ solution and diluted by $\mathrm{NaCl} 0,9 \%$ until having similar turbidity with Mc Farland (1,5 $\mathrm{x} 10^{8} \mathrm{CFU} / \mathrm{mL}$ ). Bacteria suspension was taken $100 \mu \mathrm{L}$ then put it on Mueller-Hinton agar and distributed it evenly. The next step, 8 antibiotic discs were put on Mueller-Hinton agar surface and incubated on $37^{\circ} \mathrm{C}$ for 24 hours. The inhibition zone of each antibiotic discs were measured on the next day.

Analysis of the result of bacteria sensitivity was determined by measuring inhibition zone of each antibiotic discs and compared by CLSI standart (ampicillin, gentamicin, levofloxacine, vancomycin, metronidazole, meropenem, rifampicin, and ceftriaxone), and coupled by secondary data (sensitivity test data from microbiology laboratory of Dr. Moewardi general hospital). Based on the previous result (marger primary and secondary data), so we could classify level of bacteria sensitivity on adult sepsis, included sensitive (S) or resistant (R).
This research is ethically approved by Health Research Ethics Committee Dr. Moewardi General Hospital/School of Medicine Sebelas Maret University of Surakarta. Ethical Clearance number is 476/ VII/HREC/2014.

\section{Result}

This research was carried out to determine bacteria and its resistance pattern on adult sepsis patient against some antibiotics at Dr. Moewardi general hospital in 2014. Patient distribution based on age and gender at Dr. Moewardi regional general hopital can be seen on below (table 1). Based on table 1, sepsis frequently occurs on patients who older than 49 years old.

Tabel 1 Distribution of bacteria isolates based on age and gender at Dr. Moewardi general hospital in 2014

\begin{tabular}{lcc}
\hline & Total & $\begin{array}{c}\text { Percentage } \\
(\%)\end{array}$ \\
\hline Gender & 27 & 58,70 \\
Man & 19 & 41,30 \\
Woman & 46 & 100,00 \\
Total & & \\
Age (year) & 3 & \\
20-30 & 8 & 6,52 \\
$31-40$ & 6 & 17,40 \\
$41-49$ & 29 & 13,04 \\
$>49$ & 46 & 63,04 \\
Total & & 100,00 \\
\hline
\end{tabular}

Total of bacteria isolates were 53 items. The sensitivity of 7 isolates from adult sepsis patients (September-October 2014) were tested using antibiotic discs by antibiotic disc diffusion method, and than coupled by 46 secondary data (January-March 2014) from microbiology laboratory of Dr. Moewardi general hospital.

Blood sample was taken from adult sepsis patient after the patient got empiric antibiotic treatments. Sampling before or after antibiotic treatment will affect on the result of bacteria pattern. Number of pathogen bacteria would be reduced by antibiotic treatment. But, it can be minimized by compounds (in growth media for blood sample) that neutralize the antibiotic effect, so the pathogen bacteria could grow well.

\footnotetext{
*Correspondence: andikadwimahendra@gmail.com

${ }^{1}$ Faculty of Pharmacy, Muhammadiyah University of Surakarta, Surakarta

${ }^{2}$ Faculty of Pharmacy, University of Gadjah Mada, Sekip Utara, Yogyakarta
} 
Table 2 Result of bacteria isolates from adult sepsis patients at Dr. Moewardi regional general hospital in 2014

\begin{tabular}{lcccc}
\multicolumn{1}{c}{ Bacteria } & $\begin{array}{c}\text { Primary } \\
\text { data }\end{array}$ & $\begin{array}{c}\text { Secondary } \\
\text { data }\end{array}$ & Total & Percentage $(\%)$ \\
\hline Gram-positive & & & 8 & 15,09 \\
Staphylococcus hominis & & 8 & 8 & 15,09 \\
Staphylococcus haemolyticus & 1 & 7 & 5 & 9,43 \\
Staphylococcus aureus & & 5 & 5 & 9,43 \\
Staphylococcus epidermidis & 1 & 4 & 1 & 1,89 \\
Staphylococcus capitis & & 1 & 1 & 1,89 \\
Enterobacter cloceae & & 1 & 1 & 1,89 \\
Enterococcus faecium & & 1 & 29 & $100,00 \%$ \\
Total & 2 & 27 & & \\
& & & & 13,21 \\
Gram-negative & & & 6 & 11,32 \\
Escherichia coli & 3 & 4 & 6 & 3,77 \\
Acinetobacter baumannii & 1 & 5 & 2 & 1,89 \\
Klebsiella pneumoniae & & 6 & 1 & 1,89 \\
Achromobacter xylosidant & & 2 & 1 & $100,00 \%$ \\
Proteus mirabilis & & 1 & 53 & \\
Pseudomonas aeruginosa & 1 & & & \\
Salmonella ssp & & 46 & \\
Total & 7 & & & \\
\hline
\end{tabular}

7 bacteria isolates consist of Gram-positive and Gram-negative bacteria covering Staphylococcus haemolyticus, Staphylococcus epidermidis, Acinetobacter baumannii, Pseudomonas aeruginosa, and three Escherechia coli. The seven isolates were tested their resistance against eight antibiotics (ampicillin, gentamicin, levofloxacine, vancomycin, metronidazole, meropenem, rifampicin, and ceftriaxone). The results were shown on table 3 and table 4.

In the result, all of Gram-negative were resistant to ampicillin and metronidazole, but sensitive against meropenem. Acinetobacter baumannii showed resistant to some antibiotics such as ampicillin, vancomycin, metronidazole, rifampicin, and ceftriaxone. Resistance was also shown Pseudomonas aeruginosa against ampicillin, vancomycin, metronidazole, and rifampicin. For Acinetobacter baumannii and Pseudomonas aeruginosa were sensitive to gentamicin, levofloxacine, and meropenem whereas Pseudomonas aeruginosa was sensitive to ceftriaxone.

Table 3 The result of sensitivity test of Gram-positive from adult sepsis patient

\begin{tabular}{|c|c|c|c|c|c|c|c|c|c|c|c|c|c|c|c|c|}
\hline \multirow{3}{*}{$\begin{array}{c}\text { Bacteria } \\
\text { (bacteria code) }\end{array}$} & \multicolumn{16}{|c|}{ Antibiotics } \\
\hline & \multicolumn{2}{|c|}{$\mathrm{MEM}^{1}$} & \multicolumn{2}{|c|}{$\mathrm{CN}^{1}$} & \multicolumn{2}{|c|}{$\mathrm{LEV}^{1}$} & \multicolumn{2}{|c|}{$\mathrm{VA}^{1}$} & \multicolumn{2}{|c|}{$\mathrm{MTZ}^{2}$} & \multicolumn{2}{|c|}{$\mathrm{AMP}^{2}$} & \multicolumn{2}{|c|}{$\mathrm{RD}^{2}$} & \multicolumn{2}{|c|}{$\mathrm{CRO}^{2}$} \\
\hline & $\mathrm{IZ}$ & $\mathrm{C}$ & $\mathrm{IZ}$ & $\mathrm{C}$ & $\mathrm{IZ}$ & $\mathrm{C}$ & $\mathrm{IZ}$ & $\mathrm{C}$ & $\mathrm{IZ}$ & $\mathrm{C}$ & IZ & $\mathrm{C}$ & $\mathrm{IZ}$ & $\mathrm{C}$ & $\mathrm{IZ}$ & $\mathrm{C}$ \\
\hline $\begin{array}{c}\text { Staphylococcus } \\
\text { hemolyticus } \\
\text { (618D) }\end{array}$ & 8,5 & $\mathrm{R}$ & 9 & $\mathrm{R}$ & 14 & $\mathrm{R}$ & $14,5^{*}$ & $\mathrm{R}$ & - & $\mathrm{R}$ & - & $\mathrm{R}$ & - & $\mathrm{R}$ & 17 & $\mathrm{R}$ \\
\hline $\begin{array}{l}\text { Staphylococcus } \\
\text { epidermidis } \\
\text { (68 D) }\end{array}$ & 31,7 & S & 19 & S & 28,8 & S & 13,8 & $\mathrm{R}$ & - & $\mathrm{R}$ & 23 & $\mathrm{R}$ & 12 & $\mathrm{R}$ & 17,5 & $\mathrm{R}$ \\
\hline
\end{tabular}

Three of seven bacteria isolates were Escherichia coli. Three Escherichia coli were resistant against ampicillin, gantamicin, metronidazole, and ceftriaxone. But three Escherichia coli were sensitive to meropenem. Two of the three Escherichia coli showed their resistance to levofloxacine and vancomycin. On meropenem, three Escherichia coli were sensitive to meropenem, but occured reduction of inhibition zone, $30 \mathrm{~mm}$ and 22,6 $\mathrm{mm}$ (table 4)

*Correspondence: andikadwimahendra@gmail.com

${ }^{1}$ Faculty of Pharmacy, Muhammadiyah University of Surakarta, Surakarta

${ }^{2}$ Faculty of Pharmacy, University of Gadjah Mada, Sekip Utara, Yogyakarta 
bioRxiv preprint doi: https://doi org/10.1101/044032; this version posted March 16, 2016. The copyright holder for this preprint (which was not certified by peer review) is the author/funder, who has granted bioRxiv a license to display the preprint in perpetuity. It is made available under aCC-BY-NC-ND 4.0 International license.

\section{Resistance pattern of Gram-positive}

29 isolates were earned from adult sepsis that consist of two isolates (primary data) and 27 isolates (secondary data) (table 2). Resistance patterns were performed to all of these iso- lates and the results were shown on fig. 2. Resistance also occured against erithromycin on Staphylococcus epidermidis, Staphylococcus haemolyticus, and Staphylococcus hominis (Fig. 2).

Table 4 The result of sensitivity test of Gram-negative on adult sepsis patient

\begin{tabular}{|c|c|c|c|c|c|c|c|c|c|c|c|c|c|c|c|c|}
\hline \multirow{3}{*}{$\begin{array}{c}\text { Bacteria } \\
\text { (Bacteria code) }\end{array}$} & \multicolumn{16}{|c|}{ Antibiotics } \\
\hline & \multicolumn{2}{|c|}{ MEM $^{1}$} & \multicolumn{2}{|c|}{$\mathrm{CN}^{1}$} & \multicolumn{2}{|c|}{$\mathrm{LEV}^{1}$} & \multicolumn{2}{|c|}{$\mathrm{VA}^{1}$} & \multicolumn{2}{|c|}{$\mathrm{MTZ}^{2}$} & \multicolumn{2}{|c|}{$\mathrm{AMP}^{2}$} & \multicolumn{2}{|c|}{$\mathrm{RD}^{2}$} & \multicolumn{2}{|c|}{$\mathrm{CRO}^{2}$} \\
\hline & $\mathrm{IZ}$ & $\mathrm{C}$ & $\mathrm{IZ}$ & $\mathrm{C}$ & $\mathrm{IZ}$ & $\mathrm{C}$ & $\mathrm{IZ}$ & $\mathrm{C}$ & $\mathrm{IZ}$ & $\mathrm{C}$ & $\mathrm{IZ}$ & $\mathrm{C}$ & $\mathrm{IZ}$ & $\mathrm{C}$ & $\mathrm{IZ}$ & $\mathrm{C}$ \\
\hline $\begin{array}{c}\text { Acinetobacter } \\
\text { baumannii } \\
\text { (625 D) }\end{array}$ & 25,8 & $\mathrm{~S}$ & 16 & $\mathrm{~S}$ & 23,5 & $\mathrm{~S}$ & - & $\mathrm{R}$ & - & $\mathrm{R}$ & 17 & $\mathrm{R}$ & 12,3 & $\mathrm{R}$ & 15 & $\mathrm{R}$ \\
\hline $\begin{array}{c}\text { Escherichia coli } \\
\text { (646 D) }\end{array}$ & 22,6 & $S$ & $19,75^{*}$ & $\mathrm{R}$ & $23,25 *$ & $\mathrm{R}$ & $11 *$ & $\mathrm{R}$ & - & $\mathrm{R}$ & - & $\mathrm{R}$ & 14,7 & $\mathrm{R}$ & - & $\mathrm{R}$ \\
\hline $\begin{array}{c}\text { Escherichia coli } \\
\text { (770 D) }\end{array}$ & 30 & $S$ & 7,7 & $\mathrm{R}$ & 26,7 & $\mathrm{~S}$ & $25 *$ & $\mathrm{R}$ & - & $\mathrm{R}$ & - & $\mathrm{R}$ & 21,7 & $\mathrm{~S}$ & 14,7 & $\mathrm{R}$ \\
\hline $\begin{array}{l}\text { Escherichia coli } \\
\text { (866 D) }\end{array}$ & 30 & $S$ & 19 & $\mathrm{R}$ & 26 & $\mathrm{R}$ & 21 & $\mathrm{~S}$ & - & $\mathrm{R}$ & - & $\mathrm{R}$ & 16 & $\mathrm{R}$ & 12,8 & $\mathrm{R}$ \\
\hline $\begin{array}{l}\text { Pseudomonas } \\
\text { aeruginosa } \\
\text { (790 D) }\end{array}$ & 34 & $S$ & 18,8 & $S$ & 27,8 & $S$ & - & $\mathrm{R}$ & - & $\mathrm{R}$ & - & $\mathrm{R}$ & $13 *$ & $\mathrm{R}$ & 17,5 & $\mathrm{~S}$ \\
\hline
\end{tabular}
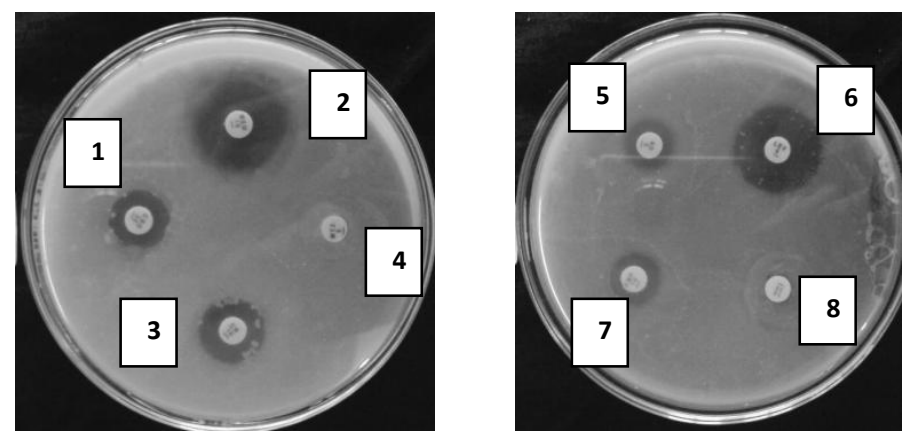

Fig. 1 Sensitivity test result by disc diffusion method on Acinetobacter baumannii

1: ceftriaxone; 2: meropenem; 3: gentamicin; 4: metronidazole; 5 : rifampicin; 6: levofloxacine; 7: ampicillin; 8: vancomycin

*Correspondence: andikadwimahendra@gmail.com

${ }^{1}$ Faculty of Pharmacy, Muhammadiyah University of Surakarta, Surakarta

${ }^{2}$ Faculty of Pharmacy, University of Gadjah Mada, Sekip Utara, Yogyakarta 


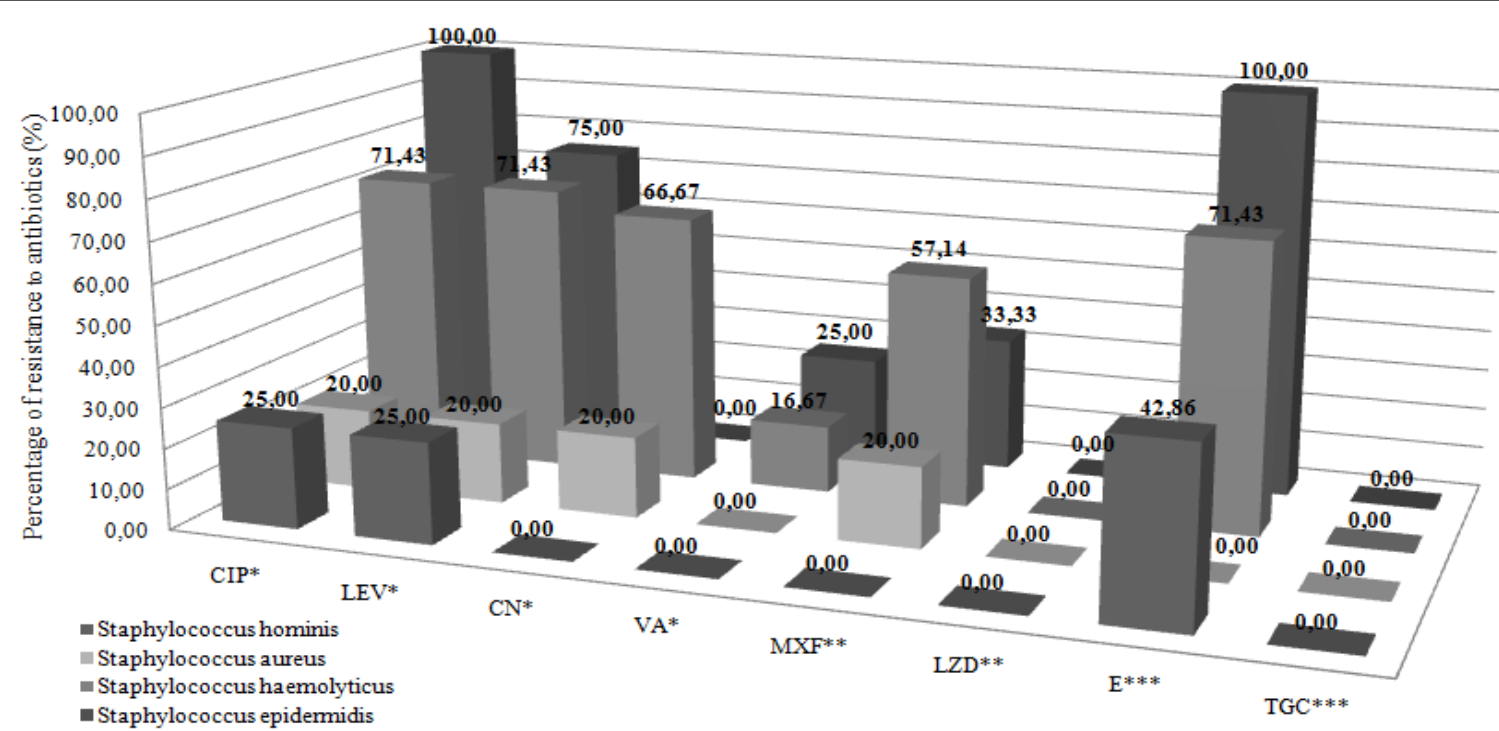

Fig. 2 Resistance pattern of Gram-positive on adult sepsis patient at Dr. Moewardi regional general hospital in 2014 *: antibiotics on antibiotic guideline for sepsis patient at Dr. Moewardi regional general hospital;

**: antibiotic recommendation for sepsis patient (Dipiro, 2007); ***: antibiotic recommendation of microbiology laboratory at Dr. Moewardi regional general hospital

Abbreviations: CIP: ciprofloxacine; E: erythromycin; LEV: levofloxacine; MXF: moxifloxacine;CN: gentamicin; VA: vancomycin; TGC: tigecycline; LZD: linezolid

The test result showed that there were some bacteria that resistant against antibiotics. Staphylococcus aureus dan Staphylococcus haemolyticus were resistant to vancomycin. On the other hand, Staphylococcus hominis was not resistant against antibiotics that were used as antibiotic recommendation for sepsis, such as gentamicin and vancomycin. All of isolated Gram-positive bacteria were sensitive against linezolide and tigecycline. Staphylococcus aureus, Staphylococcus hominis, and Staphylococcus epidermidis were sensitive to moxifloxacin, so it can be used as antibiotic for sepsis. Dipiro et al. reported that moxifloxacine and linezolid could be used as empiric antibiotic for sepsis patient. Need to be re-evaluated on antibiotic recommendation for adult sepsis patient [10].

\section{Resistance pattern of Gram-negative}

24 Gram-negative bacteria were earned from adult sepsis patient consist of 5 bacteria isolates from primary data and 24 isolates from secondary data. Escherichia coli is natural bacteria in colon, but Escherichia coli was found on sepsis patient. Not only Escherichia coli but also Acinetobacter baumannii, Klebsiella pneumoniae, Achromobacter xylosoxidant and Pseudomonas aeruginosa were found on sepsis patient.

Based on the research, Klebsiella pneumoniae, Acinetobacter baumannii, and Escherichia coli were resistant against levofloxacine, ciprofloxacine, gentamicin, amikacin. Otherwise, all of bacteria were sensitive against meropenem. Empiric antibiotic therapy for sepsis could be used meropenem $[10,11]$. Southwick reported that initial antibiotic, combination of ampicillin and amikacin, could be given when patient is diagnosed sepsis [11].

*Correspondence: andikadwimahendra@gmail.com

${ }^{1}$ Faculty of Pharmacy, Muhammadiyah University of Surakarta, Surakarta

${ }^{2}$ Faculty of Pharmacy, University of Gadjah Mada, Sekip Utara, Yogyakarta 


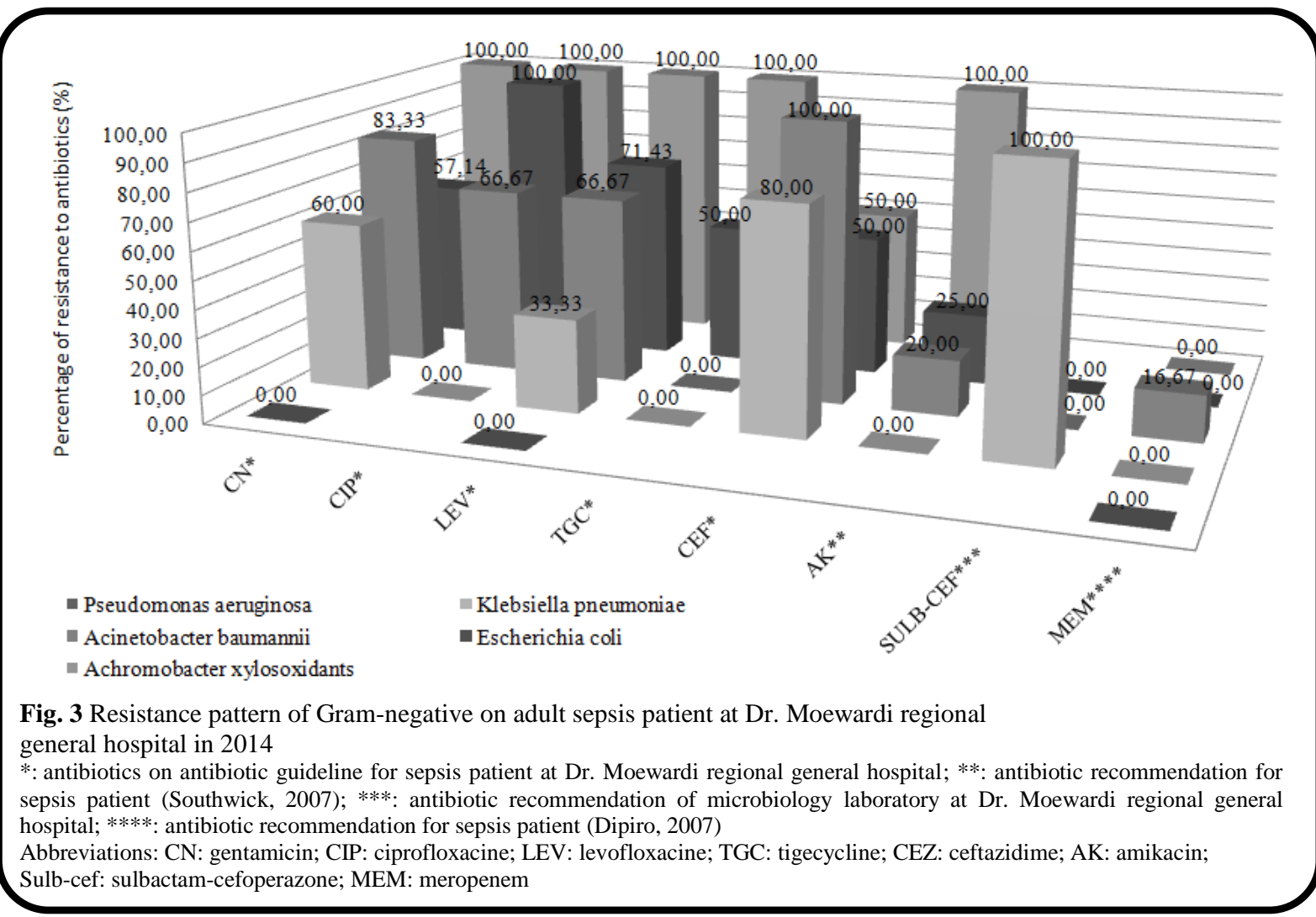

\section{Discussion}

\section{Sepsis prevalence}

Based on table 1, the state could be explained because many diseases such as influenza, pneumonia, septicemia included in the top 10 of death causes on elderly. It occurred due to the reduction of immune system [12]. A number of sepsis incidence was higher on man than woman. It was related by difference of immune responses on man and woman. Woman has good immune responses than man since woman have higher estrogen hormon. Estrogen has a role for increasing adaptive immune response. Another factor was amount of TNF (Tumor Necrosis Factor) which woman had higher than man [13].

Based on table 2, known that almost bacteria on adult sepsis was Gram-positive bacteria. Abe et al. explained that 259 sepsis patients, $65,9 \%$ were Gram-positive and 27\% were Gram-negative [14]. At the same condition at Dr. Moewardi general hospital, $54,71 \%$ were Gram-positive and 45,29\% Gram-negative on adult sepsis patient. It can be clarified that sepsis patient with Gramnegative bacteria had IL-6 and CRP (CReactive Protein) higher than Gram-positive, therefore it will make a difference *Correspondence: andikadwimahendra@gmail.com

${ }^{1}$ Faculty of Pharmacy, Muhammadiyah University of Surakarta, Surakarta

${ }^{2}$ Faculty of Pharmacy, University of Gadjah Mada, Sekip Utara, Yogyakarta mechanism of PAMPs (Pathogen-Associated Molecular Patterns) [14]. IL-6 is cytokine to regulate and increase immune system against infections and tumors [15].

\section{Resistance of Gram-positive}

Staphylococcus epidermidis is one of natural bacteria on skin and mucosa. But, the bacteria sometimes causes septicemia especially people with immune system disturbance. Staphylococcus epidermidis had an ability to form biofilm [16]. Biofilm formation by bacteria will cause resistant against antibiotic. Resistance mechanism of biofilm occured by preventing antibiotic to reach its target and decreasing efficacy of antibiotic [17]. Ziebuhr et al. reported that Staphylocoocus epidermidis, isolated from blood, had a capability to form biofilm [16]. Biofilm forming will increase bacteria resistance against antibiotic and inhibit antibiotic to reach its target [18].

Staphylococcus aureus was bacteria that cause sepsis [4]. Staphylococcus aureus was resistant against gentamicin because of antibiotic modification by acetyltransferase 
and phosphotransferase. On the other hand, another resistance mechanism on quinolone was the reduction of antibiotic affinity to DNA enzyme (topoisomerase IV and girase) [19]. Research on Gatermann et al. revealed that Staphylococcus epidermidis, Staphylococcus haemolyticus, and Staphylococcus hominis were the top 3 bacteria that resistant against erithromycin by percentage $62,5 \%, 89,8 \%$, dan $51,4 \%$, respectively [20].

Staphylococcus hominis and Staphylococcus haemolyticus are CNS (Coagulase-Negative Staphylococci) bacteria [21]. Resistance mechanism of CNS bacteria and Staphylococcus aureus by movement of plasmid (contain resistant genes) from Staphylococci as conjugation process [22].

\section{Resistance of Gram-negative}

Reduction of sensitivity on meropenem happened because of metallo $\beta$ laktamase. Escherichia coli that produce the enzyme will resistant 64-folds against meropenem. This was proven by raising MIC Escherichia coli with metallo $\beta$ laktamase $(128 \mu \mathrm{g} / \mathrm{mL})$ and without it $(2 \mu \mathrm{g} / \mathrm{mL})$ [23].

Resistance mechanism of Gram-negative bacilli through 3 resistance mechanisms those are producing enzyme to destroy antibiotic, mutation of antibiotic target, and efflux pump. A common mechanism on Gramnegative was beta lactamase production. For Enterobacteriaceae groups, resistance mechanism took place by destructing antibiotic through hydrolysis. The next resistance mechanism was a mutation of DNA gyrase and DNA topoisomerase IV and another resistance mechanism was a modification of antibiotic. Antibiotic modifications occured on aminoglycoside by aminoglycoside acetyltransferase, aminoglycoside O-nucleotidultransferase, and aminoglicoside O-phosphotransferase [25].
Generally, resistance mechanism of Pseudomonas aeruginosa against to all of antibiotic classes through reduction of cell membrane permeability and efflux pumps [25]. The usage of antibiotics ,for instance penicillin, cephalosporine, and carbapenem, would induce the bacteria to produce beta lactamase [26]. On the other hand, resistance mechanisms of Acinetobacter spp were divided into 3 categories including antibiotic inactivation by enzyme, prevention of antibiotic to reach its target, and mutation of antibiotic target. Inactivation antibiotic by Acinetobacter through producing beta lactamase and destruction of antibiotics such as penicillin, cephalosporine, and carbapenem. Some Acinetobacter strains had an ability to synthesize metallo $\beta$ lactamase for hydrolysis broad spectrum antibiotics included carbapenem. Another mechanism of Acinetobacter baumannii resistance was through efflux pump or aminoglycosidemodifying enzymes for aminoglycoside group [27].

\section{Conclusion}

Based on the research, we could conclude that bacteria pattern on adult sepsis patient at Dr. Moewardi general hospital was Staphylococcus haemolyticus $(15,09 \%)$, Staphylococcus hominis $(15,09 \%)$, Escherichia coli $(13,21 \%)$, and Acinetobacter baumannii (11,32\%). Resistance patterns with level of resistance more than $50 \%$ as Staphylococcus haemolyticus (ciprofloxacine, erithromycine, levofloxacine, moxifloxacine, and gentamycin ), Escherichia coli (gentamycin, ciprofloxacine, and levofloxacine), Acinetobacter baumannii (gentamycin, ciprofloxacine, levofloxacine, and ceftazidime).

\footnotetext{
Abbreviations

IZ: inhibition zone; S: sensitive; R: resistant; AMP: ampicillin; CN: gentamicin; LEV: levofloxacine; VA vancomycin; MTZ: metronidazole; MEM: meropenem; RD: rifampicin; CRO: ceftriaxone; CIP: ciprofloxacine; E: erythromycin; MXF: moxifloxacine; TGC: tigecycline; LZD: linezolid; CEZ: ceftazidime; AK: amikacin; Sulb-cef: sulbactam-cefoperazone; NA: Nutrient Agar; CLSI: clinical and laboratory standards institute; BHI: brain heart infusion; CFU: colony-forming units; TNF: tumor necrosis factor; IL-6: Interleukin 6; CRP: C-
} 
bioRxiv preprint doi: https://doi.org/10.1101/044032; this version posted March 16, 2016. The copyright holder for this preprint (which was not certified by peer review) is the author/funder, who has granted bioRxiv a license to display the preprint in perpetuity. It is made available under aCC-BY-NC-ND 4.0 International license.

reactive protein; PAMPs: pathogen-associated molecular patterns; DNA: deoxyribonucleic acid; CNS: central nervous system; MIC: minimum inhibitory concentration.

\section{Competing interest}

The authors declare that they have no competing interests.

\section{Authors' contributions}

ADM, MK, ITDK - Study concept and design. ADM - data collection and manuscript preparation. ADM, MK, ITDK data analysis, critically revised manuscript. ADM - Analysis and interpretation of data. All authors read and approved of the final version to be published

\section{Acknowledgements}

Microbiology lab. of Dr. Moewardi General Hospital for providing bacteria isolates. There was no external funding source for this research.

\section{Acknowledgement}

Gratefully to Allah SWT, laboratory staffs of Microbiology Dr. Moewardi regional general hospital, and staffs of Faculty of Pharmacy, MUS.

\section{Author details}

${ }^{1}$ Faculty of Pharmacy, Muhammadiyah University of Surakarta, Surakarta. ${ }^{2}$ Faculty of Pharmacy, University of Gadjah Mada, Sekip Utara, Yogyakarta

\section{References}

1. World Health Organization. Infections and infectious diseases A manual for nurses and midwives in the WHO European Region. Europe: World Health Organization; 2001.

2. Seifert H. The Clinical Importance of Microbiological Findings in the Diagnosis and Management of Bloodstream Infections. Clinical Infectious Diseases. 2009:48 suppl 4;S238-45.

3. Cunha BA. Sepsis and septic shock: selection of empiric antimicrobial therapy. Critical care clinics. 2008;24(2):313-34.

4. SWAB. SWAB guidelines for Antibacterial Antibacterial therapy of adult patients with Sepsis. Netherland: Stichting Werkgroep Antibioticabeled 2010

5. Artero A, Zaragoza R, Nogueira JM. Epidemiology of Severe Sepsis and Septic Shock. Croatia: In Tech; 2012.

6. US Department of Health and Human Services. Developing Resistance. In: Antibiotic Resistance Threats in the United States 2013. Centers for Diseases Control and Prevention. 2013. http://www.cdc.gov/drugresistance/threat-report-2013. Accessed 23 Dec 2015.

7. Duerink DO, Lestari ES, Hadi U, Nagelkerke NJD, Verbrugh HA, Keuter M, et al. Determinants of carriage of resistant Escherichia coli in the Indonesian population inside and outside hospitals, Journal of Antimicrobial Chemotherapy. 2007;60:377-84

8. Lewis MT, Biedenbach DJ, Jones RN. In Vitro Evaluation of Cefepime and Other Broad-Spectrum beta-Lactams Against Bacteria from Indonesian Medical Centers The Indonesia Antimicrobial Resistance Study. diagn microbiol infect dis. 1999;8893(99):285-90.

9. Radji M, Fauziah S, Aribinuko N. Antibiotic sensitivity pattern of bacterial pathogens in the intensive care unit of Fatmawati Hospital, Indonesia. Asian Pacific journal of tropical biomedicine. 2011;1(1);39-42.
10. Dipiro JT, Talbert RL, Yee GC, Matzke GR, Wells BG Posey LM. Pharmacotherapy A Pathophysiologic Approach, 7th ed. New York: McGraw-Hill; 2008.

11. Southwick FS. Infectious Disease A Clinical Short Course. 2nd ed. USA: McGraw-Hill; 2007.

12. Hawkley LC, Cacioppo JT. Stress and the aging immune system, Brain, Behavior, and Immunity. 2004;18(2):114-9.

13. Berkowitz DM \& Martin GS. Sepsis and Sex Can We Look Beyond Our Hormones?. Chest. 2010;132(6):1725-27.

14. Abe R, Oda S, Sadahiro T, Nakamura M, Hirayama Y, Tateishi Y, et al. Gram-negative bacteremia induces greater magnitude of inflammatory response than Gram-positive bacteremia. Critical Care. 2010;14:1-7.

15. Xing Z, Gauldie J, Cox G, Baumann H, Jordana M, Lei $\mathrm{XF}$, et al. IL-6 is an antiinflammatory cytokine required for controlling local or systemic acute inflammatory responses. The Journal of clinical investigation. 1998;101(2):311-20

16. Ziebuhr W, Krimmer V, Rachid S, Loßner I, Got F. A novel mechanism of phase variation of virulence in Staphylococcus epidermidis : evidence for control of the polysaccharide intercellular adhesin synthesis by alternating insertion and excision of the insertion sequence element IS256. Molecular Microbiology. 1999;32(2):345-56.

17. Otto M. Staphylococcal Biofilm. Curr Top Microbiol Immunol. 2008;322:207-28.

18. Zheng Z, Stewart PS. Penetration of Rifampin through Staphylococcus epidermidis Biofilms, Antimicrobial Agents and Chemotherapy. 2002;46(3):900-3.

19. Lowy FD. Antimicrobial resistance: the example of Staphylococcus aureus. Journal of Clinical Investigation. 2003;111(9):1265-73.

20. Gatermann SG, Koschinski T, Friedrich S. Distribution and expression of macrolide resistance genes in coagulase-negative staphylococci. Clinical Microbiology and Infection. 2007;13:777-81

21. John JF, Harvin AM. History and evolution of antibiotic resistance in coagulase-negative staphylococci : Susceptibility profiles of new anti-staphylococcal agents. Therapeutics and Clinical Risk Management. 2007;3(14):1143-52.

22. Huebner J, Goldmann DA. Coagulase-negative staphylococci: role as pathogens. Annual review of medicine. 1999;50:223-36.

23. Moloughney JG, Thomas JD, Toney JH. Novel IMP-1 metallo- $\beta$-lactamase inhibitors can reverse meropenem resistance in Escherichia coli expressing IMP-1. FEMS Microbiology Letters. 2005;243:65-71.

24. Kocsis B, Szabó D. Antibiotic resistance mechanisms in Enterobacteriaceae. In: A Méndez-Vilas editor. Microbial pathogens and strategies for combating them: science, technology and education. Spain: Formatex; 2013

25. Lambert PA. Mechanisms of antibiotic resistance in Pseudomonas aeruginosa. Journal of the Royal Society of Medicine. 2002;95 Suppl 4:22-26.

26. Hancock REW, Speert DP. Antibiotic resistance in Pseudomonas aeruginosa: mechanisms and impact on treatment. Drug Resistance Updates. 2000;3:247-55.

27. Maragakis LL, Perl, TM. Acinetobacter baumannii: epidemiology, antimicrobial resistance, and treatment options. Clinical Infectious Diseases. 2008;46(8):125463.

*Correspondence: andikadwimahendra@gmail.com

${ }^{1}$ Faculty of Pharmacy, Muhammadiyah University of Surakarta, Surakarta

${ }^{2}$ Faculty of Pharmacy, University of Gadjah Mada, Sekip Utara, Yogyakarta 